\title{
Effect of Coffee (Coffea Arabica L.) Strip Intercropping with Enset on Growth, Yield and Yield Aspects of the Component Crops
}

\author{
Leta Ajema*, Ashenafi Nigussie \\ Ethiopia Institute of Agricultural Research, Wondoget Agricultural Research Center, Awada Agricultural Research Sub-Center, Yirgalem, \\ Ethiopia \\ Email address: \\ letajema@gmail.com (L. Ajema) \\ ${ }^{*}$ Corresponding author
}

\section{To cite this article:}

Leta Ajema, Ashenafi Nigussie. Effect of Coffee (Coffea Arabica L.) Strip Intercropping with Enset on Growth, Yield and Yield Aspects of the Component Crops. International Journal of Photochemistry and Photobiology. Vol. 5, No. 1, 2021, pp. 7-13.

doi: $10.11648 /$ j.ijpp.20210501.12

Received: April 12, 2021; Accepted: June 9, 2021; Published: June 25, 2021

\begin{abstract}
Strip intercropping of coffee with enset could be an alternative approach to enhance resource use efficiency and land productivity, which is a common practice Southern Ethiopia. However, the optimum strip ratio of coffee to enset has been limited in the study area. In view of this, a field experiment was conducted at Awada Agriculture Research Sub-center between 2012 and 2018/19 to evaluate the effect of strip intercropping ratios of coffee to enset on yield and yield components of both crops and to determine economically optimum coffee to Enset strip intercropping ratio. The experiment was comprised of six treatments: sole coffee, sole Enset, 1C:1, 2:1, 3:1, and 4:1, and laid out in a randomized complete block design with three replications. The analysis of variance revealed that both coffee and enset growth, yield, and yield components were significantly affected by coffee-enset strip intercropping. Coffee to enset ratio of $(3: 1)$ was provided the highest pooled mean yield of coffee, closely followed by (sole coffee)) compared with others strip ratios. Concerning the economic yield of enset, sole enset offers the maximum yield related to other treatments. Similarly, the maximum total LER of 1.63 was recorded from the coffee to enset ratio of $(3: 1)$ implies a yield advantage of $63 \%$ achieved from this strip ratio. Therefore, strip intercropping of coffee to enset at 3:1 ratio could be recommended to the study area as revealed by the highest yield and total LER for sustainable production and productivity.
\end{abstract}

Keywords: Coffee, Enset, LER, Strip-Intercropping, Yield Advantage

\section{Introduction}

Intercropping system allows better resource use efficiency and reduces the need for external inputs [1]. It is a practice of growing two or more crops in the same piece of land at the same time and plays an important role in subsistence food production in developing countries [2] Strip cropping is a prominent part of an intercropping practice that two or more crops in strips are wide enough to permit independent cultivation but narrow enough for the crop to interact impartially synergistically or antagonistically. It has been well known that intercropping provides many advantages like improved utilization of growth resources by intercropped species [3]; used as a method of controlling weeds, insect pests, diseases and control of soil erosion [4]. Interactions in the component crops under intercropping facilitate each other to achieve maximum yielding or productivity [5] and cloud reduces the yield of the less competitive crops in intercropping. Ethiopia is a leading Arabica coffee producer in Africa, so that the production is concentrated in two major coffee producing regions such as Oromia (64\%) and Southern Nation Nationality and People's Regional State (SNNPRS) (35\%) and others (1\%) [6]. Sidama Zone is the largest coffee producer of SNNPRS with a share of 73,030.04ha. Coffee serves as the major cash source to the farm household, which expends the cash on its different uses. According to Damenu et al. [7], the crop is commonly 
grown as a garden plantation being intercropped with different crops such as banana, enset, and some other fruit crops. There is possibility to use citrus as a companion with coffee to generate additional household income as noted by Anteneh et al. [8]. The coffee based intercropping system provides an improved farm earning for smallholder farmers without an adverse impact on the yield and quality of coffee [9]. Enset system is one of the four major agricultural systems in Ethiopia feeding about 13 million people, more than $20 \%$ of the population residing in the southern Ethiopian highlands [10]. Despite the fact that there is no agronomic recommendation on Coffee-Enset intercropping, it is a common practice in the south and southwestern parts of Ethiopia. Enset generates system resilience to climate change, improves land-use efficiency, provides in-situ mulch, increases income and food security, and modifies the microclimate and labor efficiency of the system. However, there is no agronomic recommendation or determined the intercropping pattern of coffee with Enset in the study area. In addition to this, several production constraints like unimproved coffee cultivars produced under poor management practices, including the high-density coffee and Enset planting patterns within the limited land resource are critical production constraints that requisite solution. Therefore, the present study was carried out to address how the major enterprises of coffee with Enset cropping system can be intensified to ensure sustainable productivity in the farming system through the following specific objectives. To evaluate the effect of coffee-enset strip intercropping ratios on growth, yield, and yield components, and to determine economically sound coffee-enset strip intercropping ratio for the study area.

\section{Methodology}

\subsection{Experimental Design and Treatment Arrangements}

The experiment was conducted at Awada Agricultural Research sub-center in Sidama Zone, Southern Ethiopia. It was arranged in a randomized complete block design (RCBD) with three replications. The treatments consist of sole coffee, sole Enset, 1:1, 2:1, 3:1, and 4:1, the ratio of coffee with Enset, respectively. Fayate coffee variety released from the sub-center was used as the experimental material. One-year-old seedling of a local Enset clone locally known as Genticha was planted in the field following the rainy season at both planting cycles, when rainfall starts, at the spacing of $3 \mathrm{~m} \mathrm{x} 2 \mathrm{~m}$, insole plots, and the intra row spacing was $2.0 \mathrm{~m}$ in the intercropped plot. All desirable managements are carried out accordingly for both coffee and Enset plants.

Table 1. Treatment combination and spacing arrangement of the companion crops.

\begin{tabular}{lllll}
\hline \multirow{2}{*}{ S/N } & Coffee to Enset row ratio & Within raw spacing (m) & Remarks \\
\cline { 2 - 5 } & Treatments & Coffee & Enset \\
\hline 1 & Sole coffee & $2 \times 2$ & - & $3 \times 2$ \\
2 & $1: 1$ & $2 \times 2$ & $3 \times 2$ & $6.00 \mathrm{~m}$ \\
3 & $2: 1$ & $2 \times 2$ & $3 \times 2$ & $10.00 \mathrm{~m}$ \\
4 & $3: 1$ & $2 \times 2$ & $3 \times 2$ & $3.00 \mathrm{~m}$ \\
5 & $4: 1$ & $2 \times 2$ & $3 \times 2$ & $3.00 \mathrm{~m}$ \\
\hline
\end{tabular}

N. B: The spacing between coffee and Enset crop were three meters.

\subsection{Data Collection}

Representative trees from the central rows of each plot were identified by excluding the borders to collect yield and yield contributing characters such as plant height $(\mathrm{cm})$, height up to a primary branch, number of primary branches, number of nodes, internode length and clean coffee yield. The number of primary branches was recorded by counting the number of primary branches on the main stem and the number of nodes on the primary branch was recorded by counting the number of nodes per primary branch. The number of nodes on the main stem was measured as a total number of node count per tree. Stem girth $(\mathrm{cm})$ was measured above 5 centimeters at the ground level using a caliper meter. Canopy diameter $(\mathrm{cm})$ : Average length of tree canopy measured twice, east-west and north-south, from the widest portion of the tree canopy. Internode length on the longest primary branch $(\mathrm{cm})$ and Coffee yield $\left(\mathrm{Kg} \mathrm{ha}^{-1}\right)$. The fresh cherry weight that had already been recorded per tree bases was used and converted to clean coffee in $100 \mathrm{~kg} \mathrm{ha}^{-1}$.
Enset growth and yield parameter were also recorded by selecting the sample plant from each central plot of the experimental unit. Pseudo stem length $(\mathrm{cm})$, plant height (cm), number of green leaves, the width of green leaves $(\mathrm{cm})$, the width of leave sheath $(\mathrm{cm})$, the thickness of leaf sheath $(\mathrm{cm})$, stem weight $(\mathrm{kg})$, corm weight $(\mathrm{kg})$, kocho $(\mathrm{kg})$, and bulla $(\mathrm{kg})$ yield data were collected from the central part of each experimental unit. Land Equivalent Ratios (LER) for Coffee and Enset yield were calculated according to Willey, R. [11], procedure follows.

$$
T L E R=P L E R \text { coffee }+ \text { PLER enset }
$$

Where TLER, total land equivalent ratio; PLER coffee, Partial land equivalent ratio of coffee; PLER enset, Partial land equivalent ratio of enset. The collected data were statistically analyzed using SAS computer soft ware version 9.0 English and the significance difference between any two treatments means were tested by least significant difference (LSD) at 5\% probability level. 


\section{Result and Discussion}

\subsection{Coffee Growth Indicating Parameters}

According to the analysis of variance different strip intercropping patterns, significantly affected the plant height and stem girth at $P<0.05$ and $P<0.001$; respectively (Table 2). Plant height ranged from 206.3 to $238.52 \mathrm{~cm}$. The tallest mean plant height $(238.52 \mathrm{~cm})$ was obtained from the plot intercropped with Enset at 1:1 ratio of coffee to Enset followed by 2:1 coffee to enset ratio while the plot intercropped with $4: 1$ and 3:1 coffee-enset ratio resulted the shortest plant height of 206.3 and $209.80 \mathrm{~cm}$, respectively (Table 2 ). The tallest result of plant height would occur because of the competition of coffee plant with a densely populated Enset that was highly shaded over the plots and leading to etiolated growth to get solar radiation. Statistically, the wider stem girth (5.26) obtained from 2:1 ratio of coffee to Enset which closely followed by 3:1 coffee-enset ratio, this possibly due to shading advantage and microclimate enhancement contribution of enset to the coffee plant while the narrow (4.78) steam girth was recorded from sole planted coffee (Table 2). The thicker stem girth could bear many primary branches; each bearing many secondary branches seems to leads to higher green bean yield. Conversely, canopy diameter was not significantly caused by different intercropping patterns (Table 2). However, numerically the maximum canopy diameter was recorded at 2:1 coffee-enset intercropping pattern.

Table 2. Pooled Mean result of Coffee growth parameter affected by Enset Coffee-intercropping.

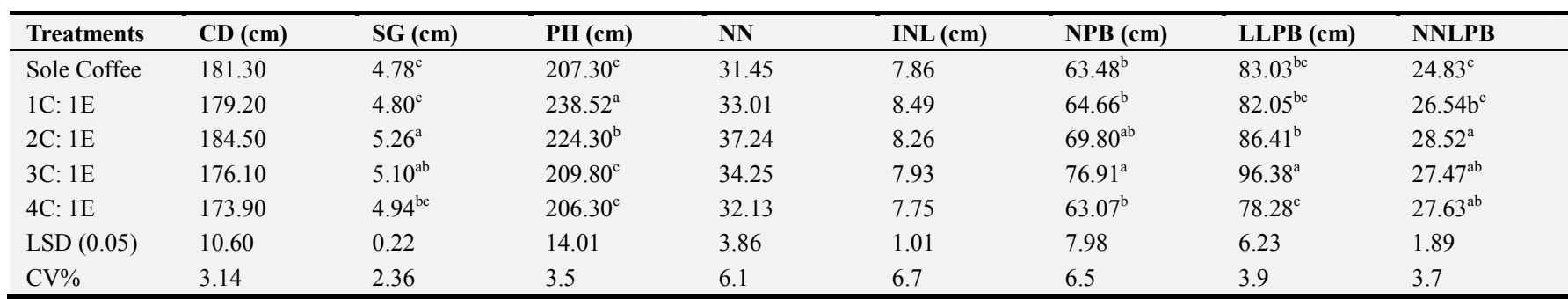

Means followed by the same letter (s) within a column are not significantly different at $\mathrm{P} \leq 0.05$.

Note: $\mathrm{CD}=$ Canopy diameter, $\mathrm{SG}=$ Stem Girth, $\mathrm{PH}=\mathrm{Plant}$ Height, NN=Node Number, $\mathrm{INL}=$ Inter node Length, NPB=Number of Primary Branch, LLPB=Length of Longest Primary Branch, NNLPB=Node Number on the Longest Primary Branch

The number of nodes, internode length, number of primary branches, length of primary branch and node number of the longest primary branch are the major yield attributes for coffee. In the present study, different intercropping patterns were significantly $(\mathrm{P}<0.05)$ affecting the number of primary branches and length of the longest primary branch. However, number of node and internode length was not yet significantly influenced by different strip intercropping patterns. The maximum (76.91) and longest (96.38) primary branch recorded from the plot where coffee intercropped with enset at 3:1 ratio (Table 2). Coffee grown with enset at $3: 1$ ratio produced 1.21 times primary branch compared with sole planted coffee. Various research findings also indicate that the number and length of primary branches is positively associated with crop yield. Mesfin and Bayetta [12] reported the positive correlation of mean yield with a length of the first primary branch and number of nodes on primary branches (0.52), number of bearing nodes on primary branches and the number of secondary branches $(0.46)$. The greater number of primary branches a coffee tree leads to getting the greater number of nodes they bear, the greater number of fruit-bearing secondary branches develop from them, and the higher the green bean yield the tree bears [13]. Similarly, node numbers on the longest primary branch were significantly $(\mathrm{P}<0.05)$ affected by intercropping of coffee with Enset. The maximum result (28.52) was recorded from coffee trees planted in 2:1 row of enset, which closely followed by $4: 1$ coffee-enset ratio while the minimum (24.83) was obtained from sole planted coffee (Table 2). The average length of primary branches, percent of bearing primary branches and leaf length, are important components to improve coffee yield [14].

\subsection{Coffee Yield Result}

Analysis of variance revealed that coffee-enset strip intercropping was significantly $(\mathrm{p}<0.05)$ affected clean coffee yield (Table 3 ). In the first and fourth harvesting season's superior yield was observed at sole planted coffee, which statistically at par with the $3 \mathrm{C}: 1 \mathrm{E}$ cropping pattern. On the contrary, during the second, third, fourth and fifth harvesting season's statistically better clean coffee yield was recorded in the treatment where coffee planted with enset at 3:1 ratio (Table 3). The result was in line with the report of [15] in which all harvesting seasons, the clean coffee yield of the sole and staggered plots was significantly different from clean coffee yields obtained from intercropped plots, except the plot with 3:1 coffee to enset ratio in 2013 and 2014 harvesting seasons. In line with this, unlike intercropping, the merits of strip cropping to minimize direct competition between shade tree and coffee plant for the available resources, viz. nutrient, moisture and light have been welldocumented [16]. Strip planting of coffee trees between two established shade tree species had enhanced coffee yield compared to intercropping under each canopy. 
Table 3. Mean result of clean coffee yields influenced by Enset to coffee intercropping.

\begin{tabular}{llllll}
\hline Treatments & $\mathbf{2 0 1 4 / 1 5}$ & $\mathbf{2 0 1 5 / 1 6}$ & $\mathbf{2 0 1 6 / 1 7}$ & $\mathbf{2 0 1 7 / 1 8}$ & $\mathbf{2 0 1 8 / 1 9}$ \\
\hline Sole Coffee & $13.56^{\mathrm{a}}$ & $12.70^{\mathrm{bc}}$ & $10.18^{\mathrm{bc}}$ & $14.20^{\mathrm{a}}$ & $18.79^{\mathrm{b}}$ \\
1C: $1 \mathrm{E}$ & $11.68^{\mathrm{bc}}$ & $11.51^{\mathrm{c}}$ & $11.36^{\mathrm{ab}}$ & $8.70^{\mathrm{c}}$ & $13.59^{\mathrm{d}}$ \\
2C: $1 \mathrm{E}$ & $10.74^{\mathrm{c}}$ & $12.62^{\mathrm{bc}}$ & $10.48^{\mathrm{abc}}$ & $9.40^{\mathrm{c}}$ & $17.55^{\mathrm{ab}}$ \\
3C: $1 \mathrm{E}$ & $12.8^{\mathrm{ab}}$ & $15.95^{\mathrm{a}}$ & $12.28^{\mathrm{a}}$ & $14.05^{\mathrm{a}}$ & $20.76^{\mathrm{a}}$ \\
4C: $1 \mathrm{E}$ & $11.44^{\mathrm{bc}}$ & $14.98^{\mathrm{ab}}$ & $10.08^{\mathrm{bc}}$ & $12.20^{\mathrm{b}}$ & $16.56^{\mathrm{c}}$ \\
LSD $(0.05)$ & 1.85 & 3.04 & 2.05 & 1.65 & 1.927 \\
CV $\%$ & 18.16 & 11.94 & 10.30 & 14.87 & 5.86 \\
\hline
\end{tabular}

Means followed by the same letter (s) within a column are not significantly different at $\mathrm{P} \leq 0.05$.

Likewise, the pooled mean analysis result showed that there was a significant variation among different strip intercropping patterns, the highest $\left(15 \mathrm{Q} \mathrm{ha}^{-1}\right)$ and lowest (11.36 $\left.\mathrm{Q} \mathrm{ha}^{-1}\right)$ recorded from coffee where intercropped with enset at 3:1 ratio and sole planted, respectively. Clean coffee yield increased by $11.27 \%$ when coffee planted with enset at
3:1 ratio compared to solitary. The number of coffee rows per two consecutive enset rows was significant $(p<0.05)$ effect on yield and yield components while row numbers increases, clean coffee yield increase up to $3: 1$ rows ratio thereafter decrease at 4:1 as illustrated in Figure 1.

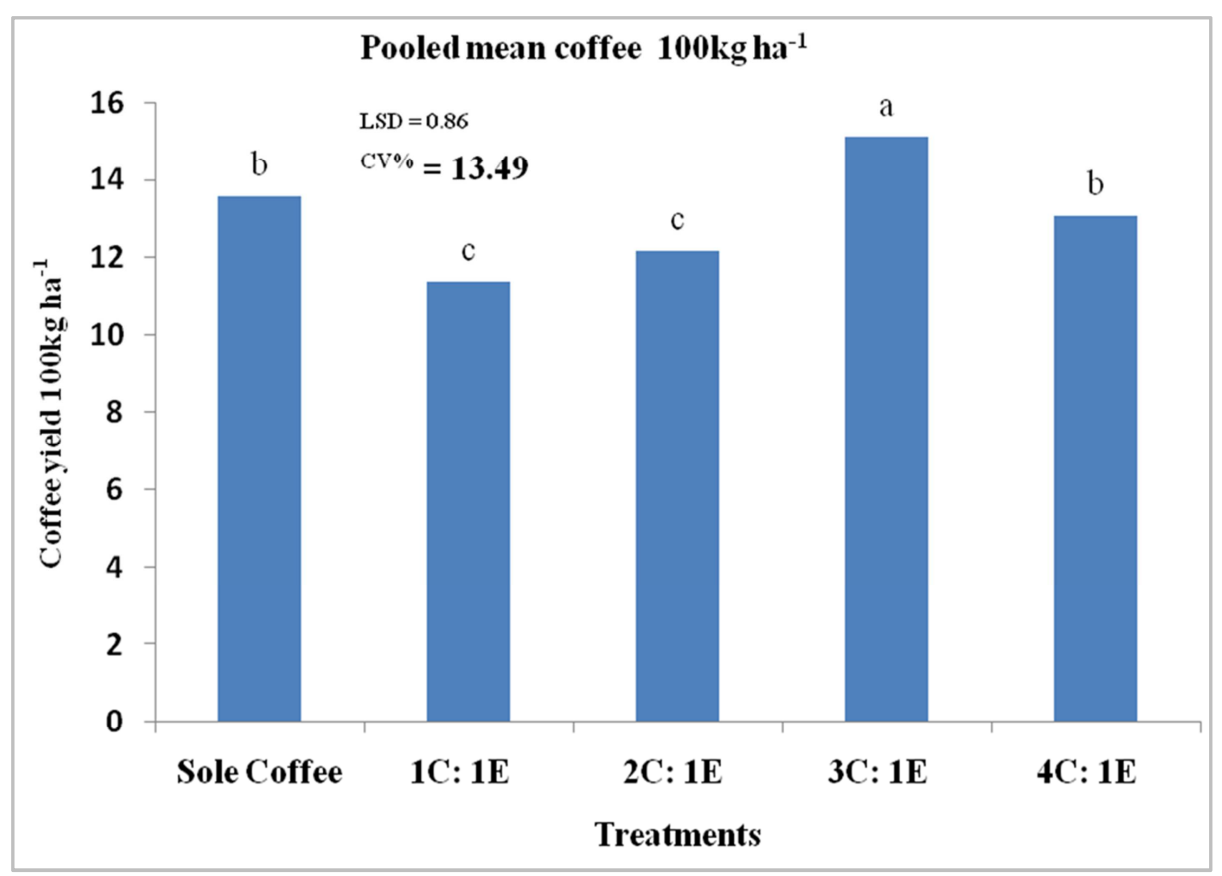

Figure 1. Pooled mean result of coffee yield recorded from each treatment.

\subsection{Enset Growth Indicating Parameters}

The data for Enset (Enset ventricosum) growth parameters are presented in Table 4. Analysis of variance depicted that pseudo stem length and circumstance were significantly $(\mathrm{p}<0.01)$ affected by different intercropping patterns (Table 4). The highest (214.08) and shortest (162.71) recorded at sole planted and 4:1 coffee-enset strip intercropping pattern, respectively. The results of this study indicated that the pseudo stem length decreased as the number of coffee rows increased between two consecutive enset rows due to diminishing mutual shading effect and competition for growth resources. Conversely, the narrow pseudo stem circumstance (145.63) recorded at sole planted enset while non-significant variation observed among different strip intercropping patterns.

Width and thickness of leaf sheath significantly affected by different intercropping patterns; sole planted enset produced minimum width and thickness of the leaf sheath (Table 4). However, different strip intercropping patterns did not show significant variation. Pseudo stem and corn weights were also significantly affected by different intercropping patterns. Even though no significant variation observed among different strip intercropping patterns, both pseudo stem and corn weights were superior at 3:1 coffee-enset strip intercropping pattern whereas, the lower value obtained at sole planted plot this could be due to the existence of higher competition on growth resources like water, nutrient and sunshine. 
Table 4. Mean result of Enset growth parameter affected by intercropping with coffee.

\begin{tabular}{|c|c|c|c|c|c|c|}
\hline Treatments & PSL (cm) & PSC (cm) & PSW (kg) & WLSH (cm) & TLSH (cm) & CW (kg) \\
\hline Sole Enset & $214.08^{\mathrm{a}}$ & $145.63^{\mathrm{b}}$ & $94.38^{\mathrm{b}}$ & $40.46^{\mathrm{b}}$ & $4.48^{\mathrm{b}}$ & $34.46^{\mathrm{b}}$ \\
\hline $1 \mathrm{C}: 1 \mathrm{E}$ & $205.63^{\mathrm{a}}$ & $173.75^{\mathrm{a}}$ & $155.54^{\mathrm{a}}$ & $47.08^{\mathrm{a}}$ & $5.25^{\mathrm{a}}$ & $48.21^{\mathrm{a}}$ \\
\hline $2 \mathrm{C}: 1 \mathrm{E}$ & $196.04^{\mathrm{ab}}$ & $183.75^{\mathrm{a}}$ & $178.71^{\mathrm{a}}$ & $44.54^{\mathrm{a}}$ & $5.08^{\mathrm{a}}$ & $51.62^{\mathrm{a}}$ \\
\hline $3 \mathrm{C}: 1 \mathrm{E}$ & $169.79^{b c}$ & $167.91^{\mathrm{a}}$ & $180.21^{\mathrm{a}}$ & $45.83^{\mathrm{a}}$ & $5.08^{\mathrm{a}}$ & $51.92^{\mathrm{a}}$ \\
\hline $4 \mathrm{C}: 1 \mathrm{E}$ & $162.71^{\mathrm{c}}$ & $183.12^{\mathrm{a}}$ & $158.63^{\mathrm{a}}$ & $44.58^{\mathrm{a}}$ & $5.21^{\mathrm{a}}$ & $49.92^{\mathrm{a}}$ \\
\hline $\operatorname{LSD}(0.05)$ & 26.33 & 21.00 & 29.06 & 2.95 & 0.49 & 11.46 \\
\hline $\mathrm{CV} \%$ & 7.37 & 6.53 & 10.05 & 3.52 & 5.19 & 12.89 \\
\hline
\end{tabular}

Means followed by the same letter ( $\mathrm{s}$ ) within a column are not significantly different at $\mathrm{P} \leq 0.05$. Note: $\mathrm{PSL}=\mathrm{Pseudo}$ stem length, PSW=Pseudo stem weight, $\mathrm{CW}=$ Corm weight, WLSH=Width of Leaf sheath, TLSH=Thickness of leaf sheath, PSC=Pseudo stem circumferences.

\subsection{Mean Yields of Enset Harvested During the $1^{\text {st }}$ and $2^{\text {nd }}$ Harvesting Cycle}

Kocho and Bula are the most economical parts of Enset. As indicated in Table 5, the cropping system significantly $(\mathrm{P}<0.05)$ affected the economic yield of the crop. In both harvesting cycles, solely planted enset gave the highest Kocho and bulla yields compared with the different strip intercropping patterns. Similarly, the total yield harvested in both cycles was significantly influenced by the different cropping systems. In the first and second harvesting cycle, the sole planted enset produced a total yield of 2.06 and 1.44 times that of the intercropped, respectively. Regarding to strip intercropping treatment, during the first harvesting cycle, statically the maximum kocho yields were recorded from one to one $(1: 1)$, while the minimum yield was recorded from three to one $(3: 1)$ and four to one (4:1) coffee-enset strip inter-cropping ratio, respectively. The Enset yield had shown a decreasing trend while number of coffee rows increased and due to the number of Enset population decrease.

Table 5. Mean yields of Enset harvested during the first and the second cycle harvesting season.

\begin{tabular}{|c|c|c|c|c|c|c|}
\hline \multirow{2}{*}{ Treatment } & \multicolumn{3}{|c|}{$1^{\text {st }}$ Cycle Yield (2015/16) } & \multicolumn{3}{|c|}{$2^{\text {nd }}$ Cycle Yield (2017/18) } \\
\hline & Kocho & Bulla & Total yield & Kocho & Bulla & Total yield \\
\hline Sole Enset & $67.46^{\mathrm{a}}$ & $2.69^{\mathrm{a}}$ & $70.15^{\mathrm{a}}$ & $60.04^{\mathrm{a}}$ & $1.32^{\mathrm{ab}}$ & $61.36^{\mathrm{a}}$ \\
\hline $1 \mathrm{C}: 1 \mathrm{E}$ & $47.33^{\mathrm{b}}$ & $2.60^{\mathrm{a}}$ & $49.93^{\mathrm{b}}$ & $51.01^{\mathrm{b}}$ & $1.50^{\mathrm{a}}$ & $52.51^{\mathrm{ab}}$ \\
\hline $2 \mathrm{C}: 1 \mathrm{E}$ & $30.71^{\mathrm{bc}}$ & $1.24^{\mathrm{b}}$ & $31.96^{\mathrm{bc}}$ & $45.56^{\mathrm{b}}$ & $1.10^{\mathrm{ab}}$ & $44.67^{\mathrm{b}}$ \\
\hline $3 \mathrm{C}: 1 \mathrm{E}$ & $28.53^{\mathrm{c}}$ & $1.13^{\mathrm{b}}$ & $29.58^{\mathrm{c}}$ & $44.66^{\mathrm{b}}$ & $1.13^{\mathrm{ab}}$ & $45.80^{\mathrm{b}}$ \\
\hline $4 \mathrm{C}: 1 \mathrm{E}$ & $23.14^{\mathrm{c}}$ & $1.05^{\mathrm{b}}$ & $24.28^{\mathrm{c}}$ & $28.40^{\mathrm{c}}$ & $0.93^{\mathrm{b}}$ & $29.33^{\mathrm{c}}$ \\
\hline $\mathrm{CV} \%$ & 24.16 & 39.72 & 23.65 & 10.56 & 21.15 & 10.46 \\
\hline
\end{tabular}

Means followed by the same letter (s) within a column are not significantly different at $\mathrm{P} \leq 0.05$.

During the second harvesting cycle, however, inconsistent trends were observed but still higher and lower yields were obtained from 1:1 and 4:1 coffee-enset strip intercropping ratio, respectively. The $1 \mathrm{C}$ : $1 \mathrm{E}$ coffee-enset strip intercropping produced significantly higher total yield and the 4C: $1 \mathrm{E}$ gave the lowest yield. There has been a total yield increment on enset by $79.03 \%$ when coffee-enset strips intercropped at $1 \mathrm{C}: 1 \mathrm{E}$ ratio compared with $4 \mathrm{C}: 1 \mathrm{E}$ ratio. In general, the result of this study showed that as number of coffee rows per two consecutive enset rows increased, enset productivity decreased simultaneously due to wider row spacing, enset population number per hectare decrease. On behalf of Enset cultivation, $3.0 \times 1.5 \mathrm{~m}$ spacing was advised that allows for one plant $4.5 \mathrm{~m}^{-2}$ and a yield of $31 \mathrm{~kg}$ plant $^{-1}$ after 2.5 years. A larger spacing of 1 plant $7.5 \mathrm{~m}^{-2}$ or spacing of $3.0 \times 2.5 \mathrm{~m}^{2}$ achieves a higher yield plant ${ }^{-1}\left(41 \mathrm{~kg} \mathrm{plant}^{-1}\right)$. However, the mean yield per hectare was considerably higher $(68.9 \mathrm{t})$ for $3.0 \times 1.5 \mathrm{~m}$ spacing compared with $54.7 \mathrm{t}$ for the $3.0 \times 2.5 \mathrm{~m}$ spacing.

\subsection{Land Equivalent Ratio (Ler)}

Land Equivalent Ratio (LER) is the most commonly used method to indicate the yield advantage of intercropping per unit area of land and biological efficiency of intercropping as compared to the mono-cropping system. The results of the current study have proved that growing two or more crops in a piece of land at the same time, is significantly advantageous and a farmer who practices intercropping gets more crops compared with one growing sole crop. It was observed that the total LER value was significantly $(\mathrm{P}<0.001)$ influenced by the intercropping ratio of coffee with Enset (Figure 1). In this study, all intercropping patters had higher LER than sole planted crops, which indicated the superiority of intercropping over monoculture. In both harvesting cycles, higher total land equivalent ratios were recorded at $1 \mathrm{C}: 1 \mathrm{E}$ (1.59), 2C:1E (1.62), and 3C:1E (1.63) than that of $4 \mathrm{C}: 1 \mathrm{E}$ (1.36). The TLER ranged from 1.36 up to 1.63 in coffee strips intercropped with enset ratio (Figure 2). This result indicated that mono cropping would require $36 \%$ up to $63 \%$ more units of land required to have the same yield compared to intercropped treatments. The association of coffee and enset at $3 \mathrm{C}: 1 \mathrm{E}$ strip intercropping ratio is vital for efficient growth and resource utilization since they are complementary to each other. These results might be attributed to more efficient total resource exploitation and greater overall 
production as opposed to the other intercrop combinations $[17,18]$. On the other hand, it is also observed that the pooled mean value of LER in the intercrops ranged from 1.36 up to 1.63 , which indicates an additional up to $63 \%$ of extra area of land would have been needed to get an equal yield to planting coffee and enset in pure stands. This result is in line with the findings of other research studies of [8, 19] who demonstrated the advantage of coffee intercropping with enset, orange, potato and spice crops, as well as a higher value of LER $(>1)$ was also recorded. Several authors [19] also reported similar results on different crops.

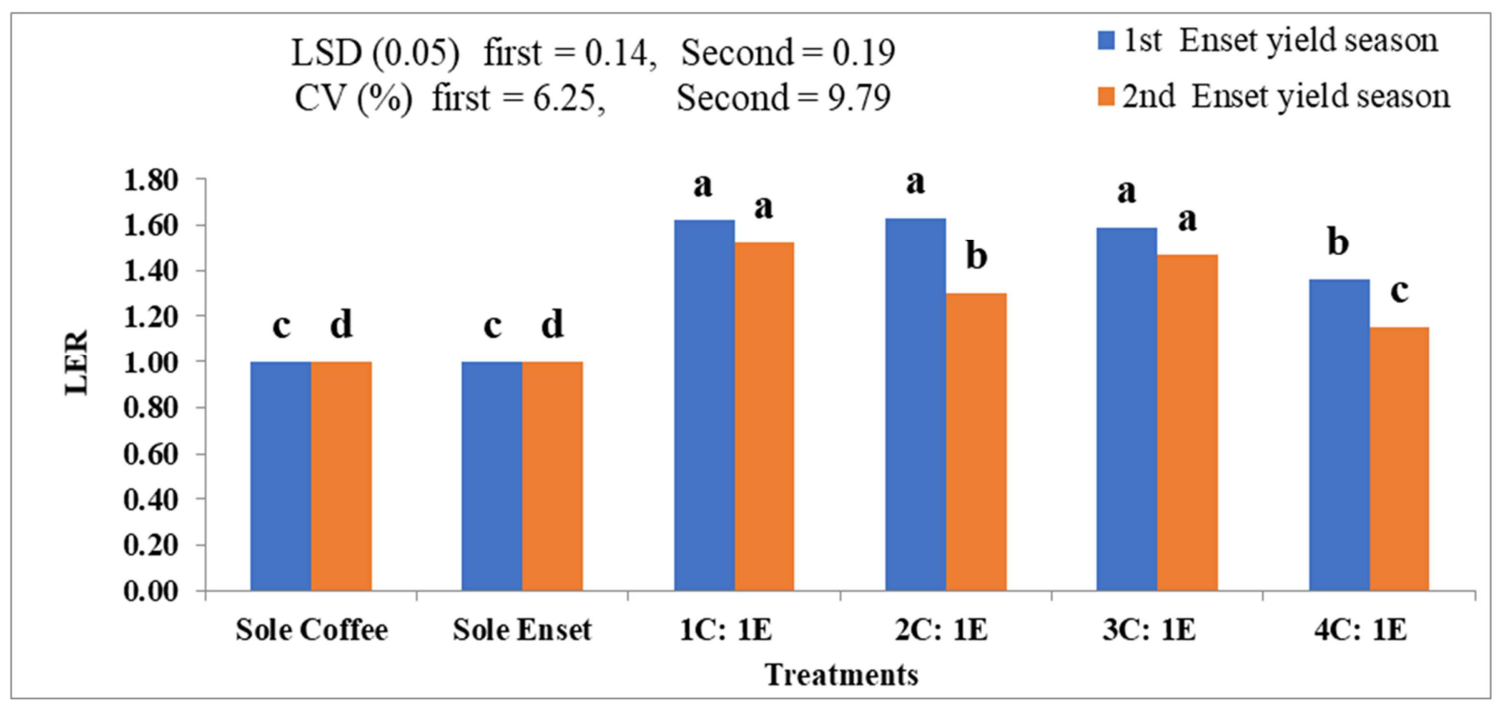

Figure 2. Total LER. Bars capped with the same letter/s are not significantly different at $(P<0.05)$.

\section{Conclusion}

The aforementioned results depicted that growth, yield, and yield components of coffee and enset were significantly influenced by coffee-enset strip intercropping. The pooled mean analysis result showed that there was a significant variation among different strip intercropping patterns, the highest (15 $\mathrm{Q}$ ha $\left.^{-1}\right)$ and lowest clean coffee yield (11.36 $\left.\mathrm{Q} \mathrm{ha}^{-1}\right)$ recorded from coffee where intercropped with enset at 3:1 ratio and sole planted, respectively. Similarly, TLER was significantly $(\mathrm{P}<0.001)$ influenced by the intercropping ratio of coffee with Enset; the highest amount of total LER 1.63 obtained in the treatment where the coffee strip intercropped with enset at 3:1 ratio, indicating strip intercropping at this level is more advantageous to produce higher yields per unit area of land through efficient utilization of growth resources. Therefore, this finding recommends that strip intercropping of coffee with enset at 3:1 ratio raised the total productivity per unit area and time to improve the land equivalent ratio and generate additional economic yield as revealed by the highest total LER.

\section{Acknowledgements}

We would like to thanks Ethiopian Institute of Agricultural Research (EIAR) for the financial support and Awada Agricultural Research Sub-Center for providing the experimental field for this study. We gratefully thanks Mr. Amare Boku, Mr. Demeke W/Mariam and Mr. Abiyot Betessa for their unreserved technical and field assistants during the courses of the work

\section{References}

[1] Dariush M, Ahad M, Meysam O. 2006. Assessing the Land Equivalent Ratio (LER) of two corn Zea mays L. varieties intercropping at various nitrogen levels in Karaj, Iran. Journal of Central European Agriculture. 7 (2): 359-364.

[2] Tsubo M, Walker S, Ogindo HO. 2005. A simulation model of cereal-legume intercropping systems for semi-arid regions: I. Model development. Field Crops Research. 93 (1): 10-22.

[3] Banik P, Midya A, Sarkar BK, Ghose SS. 2006. Wheat and chickpea intercropping. European Journal of Agronomy. 24 (4): 325-332.

[4] Matusso JMM, Mugwe JN, Mucheru-Muna M. 2012. Potential role of cereal-legume intercropping systems in integrated soil fertility management in smallholder farming systems of sub-Saharan Africa Research Application Summary. Third RUFORUM Biennial Meeting 24-28 September 2012, Entebbe, Uganda.

[5] Knudsen MT, Hauggaard-Nielsen H, Joernsgaard B, Jensen ES. 2004. Comparison of interspecific competition and $\mathrm{N}$ use in pea-barley, faba bean-barley and lupin-barley intercrops grown at two temperate locations. The Journal of Agricultural Science. 142 (06): 617-627.

[6] Birhanu T, 2017. Ethiopian coffee sector strategy and future prospects, Addis Ababa, Ethiopia.

[7] Damenu, T., Coffee production and marketing in Oromiya. In: Girma, A., Bayetta, B., Tesfaye, S., Endale, T. and Taye, K. 2008. Coffee Diversity and Knowledge. Proceedings of a National Workshop Four Decades of Coffee Research and Development in Ethiopia, Addis Ababa, Ethiopia, 485. 
[8] Anteneh N., Taye K. and Tesfaye S., 2015. Review of Arabica Coffee Management Research in Ethiopia. Journal of Biology, Agriculture and Healthcare. 5 (13): 235-258.

[9] Van Asten P., Wairegi, L., Mukasa, D. and Uringi, N., Agronomic and economic benefits of coffee-banana intercropping in Uganda's smallholder farming systems. Agricultural Systems, 104: 326-334 (2011).

[10] Amede T, and Diro M,. 2005. Optimizing Soil Fertility Gradients in the Enset (Ensete ventricosum) Systems of the Ethiopian Highlands.

[11] Willey, R, 1985. Evaluation and presentation of intercropping advantages. Experimental Agriculture, 21: 119-133.

[12] Mesfin Kebede \& Bayetta Bellachew 2008. Phenotypic diversity in the Harerge coffee (Coffee arabica L.) germplasm for quantitative traits. East African Journal of Sciences. 2: 13-18.

[13] Abdulfeta K, 2018. Characterization and Yield Performance Evaluation of Coffee (Coffea Arabica L.) germplasm Accessions from Tepi, Southwestern Ethiopia. M. Sc. Thesis Hawassa University College of Agriculture Hawassa, Ethiopia June.

[14] Atinafu G, Mohammed H., 2017. Association and Path Coefficient Analysis of Yield and Yield Attributes of Coffee
(Coffea arabica L.) Under Sidama Specialty Coffee Growing Area, Awada, Southern Ethiopia. Adv Crop Sci Tech 5: 307. doi: $10.4172 / 2329-8863.1000307$.

[15] Behailu M, Essubalew G, Shiferaw T, Tesfaye S, Anteneh N. 2020. "Intercropping of Coffee with Enset (Enset ventricosum Welw. Cheesman) at Teppi, Southwestern Ethiopia" International Journal of Research Studies in Agricultural Sciences. 6 (8): 15-22,

[16] Yacob E, Tesfaye S, Alemseged Y, Anteneh N, Takele N, Mohammednur A, Bekele B. 1996. Advances in coffee agronomy research in Ethiopia. 40-45p.

[17] Zhang, G., Yang, Z. and Dong, S., 2011. Interspecific competitiveness affects the total biomass yield in an alfalfa and corn intercropping system. Field Crops Res., 124 (1): 66-73.

[18] Thayamini H. and Brintha, I., 2010. Review on maize based intercropping. Journal of agronomy, 9 (3): 135-145.

[19] Taye, K., Anteneh, N., Tesfaye, S., Endale, T. and Alemseged, Y., 2008. Intercropping coffee with other crops. In: Girma, A., Bayetta, B., Tesfaye, S., Endale, T. and Taye, K. (Ed.). Coffee Diversity and Knowledge. Proceedings of a National Workshop Four Decades of Coffee Research and Development in Ethiopia. Addis Ababa, 485. 